\title{
ANALISIS BEBAN KERJA MENTAL PEKERJA BAGIAN GROUND HANDLING BANDARA ADISUTJIPTO UNTUK MENDUKUNG KESELAMATAN PENERBANGAN
}

\author{
Eko Poerwanto ${ }^{1}$, Gunawan ${ }^{2}$ \\ ${ }^{1}$ Teknik Industri, ${ }^{2}$ Teknik Penerbangan \\ Sekolah Tinggi Teknologi Adisutjipto \\ Jalan Janti Blok-R Lanud Adisutjipto, Yogyakarta \\ 'ekoevtas@gmail.com
}

\section{Abstract}

Increased need for air transport will increase the activity of ground handling at airports. Increased activity of this will affect the mental workload received personnel who carry it out. Any increase in mental workload will affect the occurrence of human error and affect flight safety. Analysis of mental workload of part of ground handling personnel is very important to ensure acceptable personnel workloads according to workload capacity available.

This mental workload research using NASA-TLX method, that the procedure uses a multi-dimensional rating, and divide the workload on the basis of the average loading 6 dimensions, namely Mental Demand, Physical Demand, Temporal Demand, Effort, Own Performance, and frustation. NASA-TLX is divided into two phases, namely a comparison of each scale (Paired Comparison) and giving value to the work (Event Scoring). The research objective is to ensure the mental workload of part of ground handling Adisucipto airport in Yogyakarta, in accordance with their capacity, so as to avoid human error and to support aviation safety.

The results showed that the mean score of mental workload ground handling activities by PT. Gapura Air and PT. Kokapura Avia in Yogyakarta Adisucipto airport in the mental workload optimization group, which indicates mental workload received by workers are safe (no overload).

Keywords: Mental Workload, Ground Handling, NASA-TLX

\section{Abstrak}

Peningkatan kebutuhan transportasi udara akan meningkatkan aktivitas ground handling di bandara. Peningkatan aktivitas ini akan mempengaruhi beban kerja mental yang diterima personel yang melaksanakannya. Setiap peningkatan beban kerja mental akan mempengaruhi terjadinya human error dan mempengaruhi keselamatan penerbangan. Analisis beban kerja mental personil bagian ground handling sangat penting dilakukan untuk memastikan beban kerja yang diterima personil sesuai dengan kapasitas beban kerja yang tersedia.

Penelitian beban kerja mental ini menggunakan metode NASA-TLX yang prosedurnya menggunakan rating multi dimensional, dan membagi workload atas dasar ratarata pembebanan 6 dimensi, yaitu Mental Demand, Physical Demand, Temporal Demand, 
Effort, Own Performance, dan Frustation. NASA-TLX dibagi menjadi dua tahap, yaitu perbandingan tiap skala (Paired Comparison) dan pemberian nilai terhadap pekerjaan (Event Scoring). Tujuan penelitian ini untuk memastikan beban kerja mental bagian ground handling bandara Adisutjipto Yogyakarta, sesuai dengan kapasitasnya, sehingga dapat menghindari human error dan mendukung keselamatan penerbangan.

Hasil penelitian menunjukkan bahwa skor rata-rata beban kerja mental aktivitas ground handling oleh PT. Gapura Angkasa dan PT. Kokapura Avia di bandara Adisutjipto Yogyakarta masuk dalam kelompok sedang, yang menunjukkan beban kerja mental yang diterima oleh pekerja masih aman (tidak berlebihan).

Kata kunci: Beban kerja mental, Ground Handling, NASA-TLX

\section{Pendahuluan}

Kebutuhan terhadap sarana transportasi udara saat ini mengalami peningkatan yang cukup pesat. Peningkatan kebutuhan transportasi udara ini mengakibatkan permasalahan yang cukup rumit berkaitan dengan sarana dan prasarananya yang masih terbatas. Salah satu kebutuhan yang cukup mendesak diantaranya adalah personil yang bertugas pada ground handling di bandar udara. Akibat terbatasnya sarana yang ada mengakibatkan meningkatnya beban kerja bagi operator yang bertugas, sehingga dimungkinkan adanya peningkatan beban kerja yang memungkinkan meningkatnya kelelahan dan pada akhirnya dapat meningkatnya kesalahan yang akan muncul dalam bekerja dan akan sangat membahayakan pada operasional penerbangan. Dari sudut pandang ergonomi, setiap beban kerja yang diterima oleh seseorang harus sesuai atau seimbang baik terhadap kemampuan fisik, kemampuan kognitif maupun keterbatasan manusia yang menerima beban tersebut.

Dalam dunia penerbangan, dikenal adanya tiga tahap utama dalam pelayanan, yaitu pre flight service, in flight service, dan post flight service. Pre flight service artinya kegiatan penanganan terhadap penumpang dan pesawat sebelum keberangkatan (di bandara asal/origin station). In flight service berarti kegiatan pelayanan terhadap penumpang selama di dalam pesawat. Post flight service adalah kegiatan penanganan terhadap penumpang, kargo, dan pesawat setelah penerbangan atau kedatangan (di bandara tujuan/destination). Jika dilihat dari tahapan ini, maka pekerjaan darat dalam hal ini ground handling merupakan pekerjaan atau tugas yang berat, karena pada pre flight service harus memastikan bahwa pesawat akan terbang dengan aman, dan pada post flight service memastika bahwa penumpang dan crewkabin dapat terlayani dengan baik, sehingga beban kerja menurut siklus penerbangan tersebut adalah sangat tinggi.

Penelitian ini akan dilakukan untuk memastikan bahwa beban kerja mental yang diberikan kepada bagian ground handling di bandara Adisutjipto Yogyakarta, tidak melampaui kapasitas kemampuan beban kerja yang dimiliki. Dari sudut pandang ergonomi, setiap beban kerja yang diterima oleh seseorang harus sesuai atau seimbang baik terhadap kemampuan fisik, kemampuan kognitif maupun keterbatasan manusia yang menerima beban tersebut. Hal ini sangat penting dilakukan mengingat setiap jenis kelelahan akan menyumbangkan kesalahan yang dilakukan manusia pada bidang penerbangan, dan akan mempengaruhi tingkat keselamatan yang harus dipenuhi, sesuai dengan standar internasional. 


\section{Metode Penelitian}

Metode pengukuran dengan NASA-TLX ini banyak digunakan dibandingkan metode obyektif karena cukup sederhana dan tidak membutuhkan banyak waktu serta biaya. Peneliti cukup membuat kuesioner dan menyebarkannya pada para pekerja dalam yang akan diukur beban mentalnya. Hancock dan Meshkati (1988) menjelaskan langkah-langkah dalam pengukuran beban kerja mental dengan menggunakan metode NASA-TLX.

\subsection{Penjelasan indikator beban mental yang akan diukur}

Tabel 1. Indikator beban mental yang akan diukur

\begin{tabular}{|l|l|l|}
\hline \multicolumn{1}{|c|}{ Skala } & \multicolumn{1}{|c|}{ Rating } & \multicolumn{1}{c|}{ Keterangan } \\
\hline $\begin{array}{l}\text { Mental } \\
\text { Demand }\end{array}$ & Rendah,Tinggi & $\begin{array}{l}\text { Seberapa besar aktivitas mental dan perceptual yang dibutuhkan } \\
\text { untuk melihat, mengingat dan mencari. Apakah pekerjaan tsb } \\
\text { mudah atau sulit, sederhana atau kompleks, longgar atau ketat }\end{array}$ \\
\hline $\begin{array}{l}\text { Physical } \\
\text { Demand (PD) }\end{array}$ & Rendah, Tinggi & $\begin{array}{l}\text { Jumlah aktivitas fisik yang dibutuhkan (misal: mendorong, } \\
\text { menarik, mengontrol putaran, dan lain - lain) }\end{array}$ \\
\hline $\begin{array}{l}\text { Temporal } \\
\text { Demand (TD) }\end{array}$ & Rendah, tinggi & $\begin{array}{l}\text { Jumlah tekanan yang berkaitan dengan waktu yang dirasakan } \\
\text { selama elemen pekerjaan berlangsung. Apakah pekerjaan } \\
\text { perlahan atau santai atau cepat dan melelahkan }\end{array}$ \\
\hline $\begin{array}{l}\text { Performance } \\
\text { (OP) }\end{array}$ & $\begin{array}{l}\text { Tidak tepat, } \\
\text { Sempurna }\end{array}$ & $\begin{array}{l}\text { Seberapa besar keberhasilan seseorang di dalam pekerjaannya } \\
\text { dan seberapa puas dengan hasil kerjanya }\end{array}$ \\
\hline $\begin{array}{l}\text { Frustration } \\
\text { Level (FR) }\end{array}$ & Rendah,tinggi & $\begin{array}{l}\text { Seberapa tidak aman, putus asa, tersinggung, terganggu, } \\
\text { dibandingkan dengan perasaan aman, puas, nyaman, dan } \\
\text { kepuasan diri yang dirasakan. }\end{array}$ \\
\hline Effort (EF) & Rendah, tinggi & $\begin{array}{l}\text { Seberapa keras kerja mental dan fisik yang dibutuhkan untuk } \\
\text { menyelesaikan pekerjaan }\end{array}$ \\
\hline
\end{tabular}

\subsection{Pembobotan}

Pada bagian ini responden diminta untuk melingkari salah satu dari dua indikator yang dirasakan lebih dominan menimbulkan beban kerja mental terhadap pekerjaan tersebut. Kuesioner NASA-TLX yang diberikan berupa perbandingan berpasangan. Dari kuesioner ini dihitung jumlah tally dari setiap indikator yang dirasakan paling berpengaruh. Jumlah tally menjadi bobot untuk tiap indikator beban mental.

\subsection{Pemberian Rating}

Pada bagian ini responden diminta memberi rating terhadap keenam indikator beban mental. Rating yang diberikan adalah subyektif tergantung pada beban mental yang dirasakan oleh responden tersebut. Untuk mendapatkan skor beban mental NASA-TLX, bobot dan rating untuk setiap indikator dikalikan kemudian dijumlahkan dan dibagi dengan 15 (jumlah perbandingan berpasangan). 


\subsection{Menghitung nilai produk}

Diperoleh dengan mengalikan rating dengan bobot faktor untuk masing-masing deskriptor (lihat Persamaan 1). Dengan demikian dihasilkan 6 nilai produk untuk 6 indikator (MD : mental demand, $\mathrm{PD}$ : physical demand, TD : temporal demand, $\mathrm{CP}$ : condition performance, $\mathrm{FR}$ : frustration rating, $\mathrm{EF}$ : effort rating)

$$
\text { Produk }=\text { rating } \mathrm{x} \text { bobot faktor }
$$

\subsection{Menghitung Weighted Workload (WWL)}

Diperoleh dengan menjumlahkan keenam nilai produk (lihat Persamaan 2)

$$
W W L=\sum \operatorname{produk}
$$

\subsection{Menghitung rata-rata WWL}

Diperoleh dengan membagi WWL dengan jumlah bobot total (lihat Persamaan 3).

$$
\text { skor }=\frac{\text { K(bobot } \times \text { rating })}{15}
$$

\subsection{Interpretasi Skor}

Berdasarkan penjelasan Hart dan Staveland (1981) dalam teori NASA-TLX, skor beban kerja yang diperoleh terbagi dalam tiga bagian yaitu pekerjaan menurut para responden tergolong agak berat jika nilai $>80$, nilai 50-80 menyatakan beban pekerjaan sedang, sedangkan nilai $<50$ menyatakan beban pekerjaan agak ringan.

Aktivitas ground handling menjadi suatu tumpuan atau harapan penting terhadap perusahaan penerbangan, karena pelayanan yang memuaskan/ prima (satisfaction) dapat dilihat dari kecepatan dan ketepatan salah satunya dalam menangani ground handling. Semakin tinggi On Time Performance (OTP) semakin baik, dengan jadwal penerbangan menjadi tidak terganggu atau sesuai dengan jadwal yang telah ditetapkan. Karena itu perusahaan penerbangan terus meningkatkan On Time Performance guna menciptakan kepuasan untuk para penumpangnya. On Time Performance merupakan satu paket yang harus dapat dicapai oleh personil ground handling, sehingga personil ground handling berusaha keras agar tercapai On Time Performance.

\section{Hasil dan Pembahasan}

\subsection{Jenis Aktivitas pada Ground Handling}

Gambar 1 merupakan proses perawatan pesawat terbang pada Aircraft Maintenance Training Organization (AMTO) selalu mewajibkan melakukan prosedur engine ground run setelah dilakukan perawatan pesawat terbang Pada dasarnya fasilitas laboratorium perawatan pesawat harus memenuhi standar yang telah ditetapkan yaitu:

Mengacu pada IATA Aircraft Handling Manual (AHM) 810 Annex A, tahun 2004 yang menetapkan sebanyak 8 section pelayanan standar, selengkapnya sebagai berikut:

Section 1: Representation, Administration \& Supervision

\subsection{General \\ 1.2. Administrative function}


1.3. Supervision and/or coordination of services contracted by the carrier with third party(ies)

Section 2: Passenger Services

2.1. General

2.2. Departure

2.3. Arrival

2.4. Remote/off airport services

2.5. Intermoda transportation by rail, road or sea.

Section 3: RAMP Services

3.1. Baggage Handling

3.2. Marshalling

3.3. Parking

3.4. Cooling and heating

3.5. Ramp to flight deck communication

3.6. Loading and unloading

3.7. Starting

3.8. Safety Measures

3.9. Moving of aircraft

3.10. Exterior cleaning

3.11. Interior cleaning

3.12. Toilet services

3.13. Water services

3.14. Cabin services

3.15. Storage of cabin material

3.16. Catering ramp handling

3.17. De-icing/anti-icing services and snow/ice removal

Section 4: Load Control, Communication \& Flight Operations

4.1. Load control

4.2. Communications

4.3. Flight operations-general

4.4. Flight operations - flight preparations at the airport of departure

4.5. Flight operations - flight preparations at a point different from the airport of departure

4.6. Flight operations - en.route flight assistance

4.7. Flight operations - post flight activities

4.8. Flight operations - en.route re.despatch

4.9. Flight operations - crew administration

Section 5: Cargo \& Mail Services

5.1. Cargo \& mail handling-general

5.2. Customs control

5.3. Irregularities handling

5.4. Document handling

5.5. Physical handling outbound inbound

5.6. Transfer/transit cargo

5.7. Post office mail

Section 6: Support Services 
6.1. Accomodation

6.2. Automation/computer systems

6.3. Unit Load Device (ULD) control

6.4. Fuel farm (depot)

6.5. Ramp fuelling/defueling operations

6.6. Replenishing of oils and fluids

6.7. Surface transport

6.8. Catering services - liason and administration

Section 7: Security

7.1. Passenger and baggage screening and reconciliation

7.2. Cargo and post office mail

7.3. Catering

7.4. Aircraft security

7.5. Additional security services

Section 8: Aircraft Maintenace

8.1. Routine services

8.2. Non-routine services

8.3. Material handling

8.4. Parking and hangar space

Tipe pelayanan yang diberikan oleh perusahaan Ground Handling Services (type of ground handling aggrement), dibedakan menjadi tiga jenis penanganan pelayanan sebagai berikut (Majid, S.A., dan Wardani, E.P.D., 2008) :

1. Full Handling, yaitu menangani seluruh section pelayanan sesuai standar yang telah ditetapkan oleh IATA.

2. Part of Handling Services, yaitu menangani sebagian dari section pelayanan yang telah ditetapkan oleh IATA.

3. Technical Handling, yaitu menangani pelayanan yang bersifat teknis dari section yang telah ditetapkan oleh IATA.

Ada beberapa jenis aktivitas ground handling yang diukur beban kerja mentalnya dengan menggunakan metode NASA TLX sesuai dengan tugas masing-masing personil ground-crew, yaitu :

1. Flight Operation Officer (FOO), bertugas menghitung performance pesawat untuk menentukan batasan berat pada saat tinggal landas maupun pada saat mendarat; menghitung kesetimbangan pesawat agar pesawat tetap setimbang (menghitung Central of Grafity) dan mendapatkan pembakaran bahan bakar (fuel) yang paling ekonomis; menganalisis cuaca di stasiun keberangkatan, alternate dan kedatangan untuk memastikan cuaca di seluruh stasiun di atas kondisi cuaca yang distandarkan oleh badan yang berwenang (weather above minima); menganalisis Notice to Airman (NOTAM) untuk memastikan kondisi seluruh stasiun dan sepanjang jalan penerbangan (en-route) tidak ada yang significant mempengaruhi operasi penerbangan; merencanakan rute penerbangan, ketinggian, stasiun alternate, berat pesawat, bahan bakar dan lain-lain berdasarkan analisis diatas; melakukan briefing ke pilot sebelum penerbangan dilaksanakan; bersama-sama pilot menandatangani dispach release sebagai tanda bahwa rencana penerbangan sudah aman ( $\mathrm{safe}$ ), ekonomis, nyaman buat penumpang dan di sepakati kedua belah pihak (mutual agreement) sebelum penerbangan dilaksanakan; 
setelah pesawat mengudara FOO juga memantau penerbangan untuk memberikan bantuan ke pilot jika di perlukan serta memberikan informasi perkembangan cuaca atau informasi penting lainnya yang berhubungan dengan penerbangan itu, pematauan ini dilakukan terus menerus sampai pesawat mendarat dan misi penerbangan dianggap selesai.

2. Ramp Officer, bertugas mengkoordinir seluruh kegiatan ground handling di apron.

3. Pasasi, Counter Check-in, bertugas menangani penumpang dimulai dari proses check in hingga penumpang naik ke pesawat (Aircraft), dan menangani proses penumpang transit.

4. Greeting/gate, bertugas mempersiapkan penumpang untuk masuk kedalam pesawat serta menghitung jumlah penumpang yang ada, untuk disesuaikan dengan jumlah penumpang masuk yang terdapat di sistem check-in, serta menyambut penumpang ketika turun dari pesawat dan mengarahkan penumpang tersebut menuju pintu kedatangan (arrival).

5. Loadmaster, bertugas mengawasi pemuatan bagasi dan cargo sesuai dengan rencana

6. Aviation Security, bertugas mengamankan kegiatan yang dilakukan pada saat penumpang memasuki gerbang bandara atau pintu masuk kebandara. Di mana dilakukan pengecekan terhadap penumpang mulai dari barang bawaan penumpang sampai tiket penumpang.

7. Lost and Found (L/L), bertugas mengecek bagasi penumpang dengan cara menyamakan nomor bagasi yang ada di label bagasi masing-masing penumpang, serta mengurus kelebihan, kehilangan dan kerusakan bagasi yang dialami penumpang.

8. Cabin Cleaning, bertugas membersihkan bagian dalam pesawat.

9. Marshalling, bertugas memandu parkir pesawat pada saat kedatangan.

10. Porter, bertugas melakukan loading/ unloading sesuai rencana pemuatan.

\subsection{Pengukuran Beban Mental Aktivitas pada Ground Handling dan Pembahasan}

Berdasarkan indikator beban kerja mental pada aktivitas ground handling dan jenis aktivitas ground handling yang diamati pada penelitian ini, maka dilakukan pengukuran beban kerja mental terhadap aktivitas ground handling di bandara Adisutjipto Yogyakarta. Operator ground handling di bandara Adisutjipto Yogyakarta ada empat, tetapi pengamatan hanya dilakukan di dua operator yaitu PT. Gapura Angkasa dan PT. Kokapura Avia.

\subsubsection{Pengukuran dan Pembahasan Beban Kerja Mental Aktivitas Ground Handling di PT. Gapura Angkasa.}

PT. Gapura Angkasa merupakan operator ground handling yang melayani penerbangan dari Garuda Group, yaitu Garuda Indonesia Airline dan Citilink. Berdasarkan pengukuran beban kerja mental yang telah dilakukan menghasilkan skor rata-rata sebagai berikut (lihat Tabel 2.)

Besarnya beban kerja mental pada aktivitas ground handling oleh personel PT. Gapura Angkasa di bandara Adisutjipto Yogyakarta menunjukkan rata-rata skor: 74,1734941 dan menurut penjelasan Hart dan Staveland (1981) dalam teori NASA-TLX termasuk dalam kelompok sedang (Optimal). Menurut Hart dan Staveland (1981) skor beban kerja yang diperoleh terbagi dalam tiga bagian yaitu pekerjaan menurut para responden tergolong agak berat jika nilai $>80$, nilai 50-80 menyatakan beban pekerjaan sedang, sedangkan nilai $<50$ menyatakan beban pekerjaan agak ringan. Hal ini menunjukkan aktivitas ground handling di PT. Gapura Angkasa sudah optimal, dan akan beresiko jika ada penambahan pelayanan penerbangan tetapi tidak diimbangi dengan penambahan personel yang akan menangani. 
Tabel 2. Skor Rata-rata Beban Kerja Mental pada PT. Gapura Angkasa

\begin{tabular}{|c|c|c|}
\hline No & Unit & Skor rata-rata \\
\hline 1 & FOO: Flight Operation Officer & 79 \\
\hline 2 & Ramp Officer & 75.51851852 \\
\hline 3 & Pasasi, Counter Check-in & 71.48 \\
\hline 4 & Greeting/gate & 71.30965909 \\
\hline 5 & Loadmaster & 71.96666667 \\
\hline 6 & Avsec $=$ Aviation Security & 74.38095238 \\
\hline 7 & Lost and Found (L/L) & 76.88888889 \\
\hline 8 & Aircraft Cleaning & 74.85 \\
\hline 9 & GSE : Ground Support Equipment & 74.63333333 \\
\hline 10 & Marshalling & 76.29166667 \\
\hline \multirow[t]{2}{*}{11} & Porter & 69.58875 \\
\hline & Skor rata-rata total & 74.1734941 \\
\hline
\end{tabular}

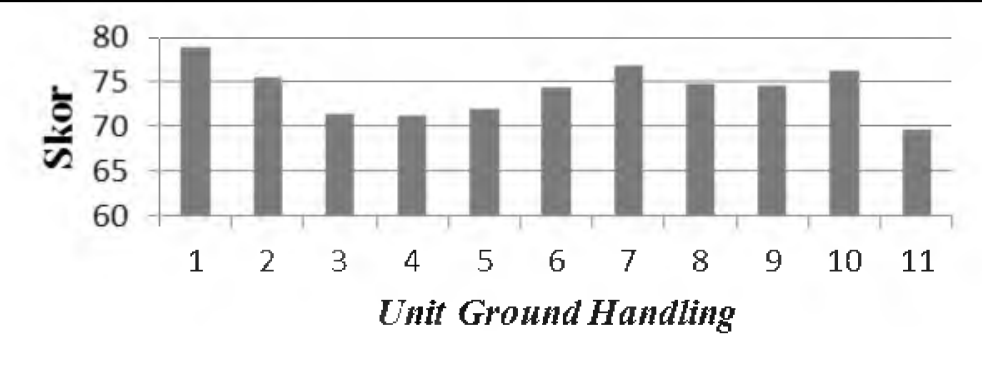

Gambar 1. Grafik Skor Beban Kerja Mental Rata-Rata Aktivitas Ground-Crew di PT. Gapura Angkasa

Pengukuran beban kerja mental menunjukkan skor rata-rata tertinggi dihasilkan pada unit Flight Operation Officer (FOO). Hal ini sangat mudah dipahami karena memang tugas dan tanggungjawab FOO sangat besar, yaitu mulai dari pesawat datang dan mendarat di bandara kemudian terbang lagi dan sampai di bandara tujuannya. Sedangkan skor rata-rata kedua yaitu unit Lost and Found (L/L) yaitu sebesar 76,88888889. Hal ini menunjukkan bahwa beban kerja mental ada di ujung-ujung bagian tugas di industri penerbangan. FOO merupakan unit yang menangani pelayanan sebelum pesawat mendarat dan Lost and Found merupakan unit yang melayani penumpang sebelum meninggalkan terminal/ bandara untuk pengecekkan terakhir antara penumpang dan barang bawaannya.

\subsubsection{Pengukuran dan Pembahasan Beban Kerja Mental Aktivitas Ground Handling di PT. Kokapura Avia.}

PT. Kokapura Avia merupakan salah satu operator ground handling di bandara Adisutjipto Yogyakarta yang melayani aktivitas penerbangan Lion Group, Express Air dan Air Charter Unschedul Flight. Pengukuran beban kerja mental aktivitas ground handling di PT. Kokapura Avia menghasilkan skor rata-rata pada tiap unit aktivitas, sebagai berikut : 
Tabel 3. Skor Rata-rata Beban Kerja Mental pada PT. Kokapura Avia

\begin{tabular}{|c|c|c|}
\hline No & Unit & Skor rata-rata \\
\hline 1 & FOO : Flight Operation Officer & 79.2222 \\
\hline 2 & Ramp Officer & 77.1481 \\
\hline 3 & Pasasi, Counter Check-in & 73.4762 \\
\hline 4 & Greeting/gate & 71.3097 \\
\hline 5 & Loadmaster & 71.9123 \\
\hline 6 & Avsec $=$ Aviation Security & 74.381 \\
\hline 7 & Lost and Found $(\mathrm{L} / \mathrm{L})$ & 77.6429 \\
\hline 8 & Aircraft Cleaning & 75.2745 \\
\hline 9 & GSE : Ground Support Equipment & 76.6667 \\
\hline 10 & Marshalling & 76.1111 \\
\hline 11 & Porter & 72.4622 \\
\hline & Rata-rata Skor Total & 75.06 \\
\hline
\end{tabular}

Besarnya beban kerja mental pada aktivitas ground handling oleh personel PT. Kokapura Avia di bandara Adisutjipto Yogyakarta menunjukkan rata-rata skor: 75,06 dan menurut penjelasan Hart dan Staveland (1981) dalam teori NASA-TLX termasuk dalam kelompok sedang (Optimal). Menurut Hart dan Staveland (1981) skor beban kerja yang diperoleh terbagi dalam tiga bagian yaitu pekerjaan menurut para responden tergolong agak berat jika nilai $>80$, nilai 50-80 menyatakan beban pekerjaan sedang, sedangkan nilai $<50$ menyatakan beban pekerjaan agak ringan. Hal ini menunjukkan aktivitas ground handling di PT. Kokapura Avia sudah optimal, dan akan beresiko jika ada penambahan pelayanan penerbangan tetapi tidak diimbangi dengan penambahan personel yang akan menangani.

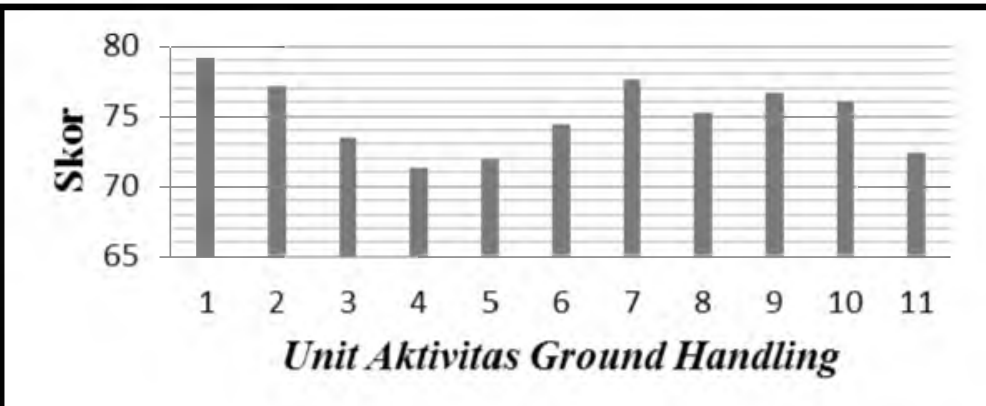

Gambar 2. Grafik Skor Beban Kerja Rata-Rata Aktivitas Ground Handling di PT. Kokapura Avia

Hasil pengukuran dan perhitungan menunjukkan skor rata-rata total beban kerja mental di PT. Kokapura Avia lebih tinggi $(75,06>74,1734941)$ dari pada beban mental di PT. Gapura Angkasa. Hal ini menurut manajer PT. Kokapura Avia sangat dipahami dan dimungkinkan karena seringnya terjadi delay dari penerbangan sebelumnya, sehingga berefek dan berantai pada pelayanan berikutnya yang menyertai. Hal ini sudah sesuai dengan pernyataan Direktur Angkutan Udara, Ditjen Perhubungan Udara menjelaskan bahwa, 
maskapai dengan tingkat OTP di bawah Garuda Indonesia adalah Wings Air dengan OTP 80,77\%, diikuti oleh Sriwijaya Air dengan OTP 79,77\%, dan Lion Air dengan OTP 73,95\%.

Menurut pernyataan Direktur Angkutan Udara, Ditjen Perhubungan Udara, sebagian besar keterlambatan penerbangan disebabkan oleh faktor-faktor lain yaitu faktor-faktor selain faktor teknis operasional, non teknis operasional, dan faktor cuaca sebesar 40.349 (39\%). Sedangkan penyebab keterlambatan terbanyak ke-2, disebabkan oleh faktor non teknis operasional sebesar $33.563(32,44 \%)$. Keterlambatan penerbangan yang disebabkan oleh faktor non teknik operasional misalnya keterlambatan awak kabin karena transportasi, keterlambatan dari bandara asal, over booking, connecting flight crew, menunggu pembuatan dokumen penerbangan (airline performance). Penyebab keterlambatan penerbangan ke-3 adalah faktor teknis operasional sebesar $23.606(22,82 \%)$ diantaranya yaitu terjadinya antrian pesawat udara lepas landas (take off), mendarat (landing), atau alokasi waktu keberangkatan (slot time) di bandar udara (airport performance).

Selain meningkatkan On Time Performance (OTP) hendaknya seluruh komponen pada industri penerbangan harus meningkatkan tingkat keselamatan penerbangan. Salah satu aspek yang paling menonjol sebagai penyebab kecelakaan pesawat terbang di dunia ini adalah human factor atau faktor manusia yang mengoperasikan pada industri penerbangan. Jika dilihat dari manusia yang terlibat di industri penerbangan, maka ada dua kelompok yaitu flight-crew dan ground-crew. Berkaitan dengan hal ini penelitian yang membahas tentang kedua kelompok komponen pada industri penerbangan di Indonesia ini, harus ditingkatkan untuk dapat meningkatkan keselamatan penerbangan di Indonesia. Tujuan ini harus selalu didukung oleh seluruh stakeholder untuk meningkatkan peringkat penerbangan di Indonesia menuju peringkat 1 , yaitu penerbangan yang aman dan patuh terhadap regulasi penerbangan Internasional.

\section{Kesimpulan dan Saran}

Berdasarkan hasil dan pembahasan pada sebelumnya, ada beberapa kesimpulan yang dapat diberikan :

1. Kondisi beban kerja mental bagian ground handling bandara Adisutjipto menunjukkan skor rata-rata sebesar 74,1734941 untuk PT. Gapura Angkasa dan 75,06 untuk PT. Kokapura Avia. Besarnya beban kerja mental tersebut menurut penjelasan Hart dan Staveland (1981) dalam teori NASA-TLX termasuk dalam kelompok sedang (optimal). Menurut Hart dan Staveland (1981) skor beban kerja yang diperoleh terbagi dalam tiga bagian yaitu pekerjaan menurut para responden tergolong agak berat jika nilai $>80$, nilai 50 80 menyatakan beban pekerjaan sedang, sedangkan nilai $<50$ menyatakan beban pekerjaan agak ringan.

2. Kondisi beban kerja mental untuk aktivitas ground handling di bandara Adisutjipto Yogyakarta, khususnya yang dilayani oleh PT. Gapura Angkasa dan PT. Kokapura Avia masih aman, karena belum masuk kelompok berat/ tinggi. Tetapi dengan trend naiknya pengguna angkutan udara sangat memungkinkan adanya tambahan jadwal penerbangan di bandara Adisutjipto Yogyakarta. Hal ini harus diimbangi dengan menambahkan personel untuk pelayanan ground handling, karena kondisi saat ini sudah optimal.

3. Skor rata-rata tertinggi beban kerja mental untuk aktivitas ground-crew di bandara Adisutjipto Yogyakarta pada kedua operator ground handling adalah pada unit Flight Operation Officer (FOO). Hal ini menunjukkan unit yang mempunyai beban tanggungjawab 
terbesar untuk lancarnya operasional penerbangan menuju penerbangan yang On Time Performance (OTP) yang tinggi.

Berdasarkan kesimpulan seperti diuraikan di atas, maka beberapa saran yang dapat diberikan pada penelitian ini:

1. Penelitian dapat dilanjutkan untuk mencari faktor-faktor yang mempengaruhi tingginya beban kerja mental pada unit Flight Operation Officer (FOO) dan bagaimana strategi atau metode untuk menguranginya.

2. Mengingat aspek human factor merupakan kontribusi terbesar terjadinya kecelakaan pesawat terbang. Penelitian dapat dikembangkan mengamati beban kerja mental untuk personel aircraft maintenance, dan lainnya

\section{Ucapan Terima Kasih}

Penulis sangat berterima kasih atas bantuan PT. Gapura Angkasa dan PT Kokapura Avia bandara Adisutjipto Yogyakarta yang telah memberikan ijin pengukuran beban kerja mental untuk personel ground-crewnya. 


\section{Daftar Pustaka}

Aisyah, A. \& Purwaningsih, R., 2013, Analisis Pengaruh Temperatur Lingkungan Kerja, Berat Badan dan Tingkat Beban Kerja Terhadap Denyut Nadi (Studi Kasus Ground Handling Bandara Ahmad Yani Semarang), Industrial Engineering Online Journal, Program Studi Teknik Industri Fakultas Teknik Universitas Diponegoro, Volume 2, Nomor 4, Tahun 2013.

Budiman, J., Pujangkoro, S.A., \& Anizar., 2013, Analisis Beban Kerja Operator Air Traffic Control Bandara XYZ Dengan Menggunakan Metode NASA-TLX, e-Jurnal Teknik Industri FT USU Vol 3, No. 3, Oktober 2013 pp. 15-20

Garuda Indonesia, 2009. Laporan Tahunan / Annual Report.

Hancock \& Meshkati, 1988, Human Mental Workload, Elsevier Science Publisher B.V., New York, USA.

Hart \& Staveland 1981, dalam DiDomenico dan Nussbaum, 2007. The Workload. Jakarta. Universitas Indonesia Press.

Hendrawan, B., Ansori, M.. \& Hidayat, R., 2013., Pengukuran dan Analisis Beban Kerja Pegawai Bandara Hang Nadim, Jurnal Akuntansi, ekonomi dan Manajemen Bisnis, Politeknik Negeri Batam volume ke 1 Nomor 1, Juli 2013, ISSN: 2337-7887.

Kementrian Perhubungan, 2014., Buku 1 Statistk Perhubungan 2014.

Majid, S.A., dan Wardani, E.P.D., 2008, Ground Handling Manajemen Pelayanan Darat Perusahaan Penerbangan, Sekolah Tinggi Manajemen Transport (STMT) Trisakti, Rajawali Pers, Divisi Buku Perguruan Tinggi, PT Raja Grafindo Persada, Jakarta, ISBN 978-979-769-244-5

Nurmianto, Eko, 2004, Ergonomi Konsep Dasar dan Aplikasinya. Edisi Kedua.Guna Widya. Surabaya.

Peraturan Menteri Perhubungan, PM nomor 38 tahun 2015 tentang Standar Pelayanan Penumpang Angkutan Udara dalam Negeri.

Suma'mur, P. K., 1996, Hygiene Perusahaan dan Keselamatan Kerja, Cetakan Kedua. CV. Haji Mas Agung. Jakarta.

Tarwaka, Bakri, S.H.A. Sudiajeng L. Ergonomi untuk Keselamatan, Kesehatan Kerja dan Produktivitas. UNIBA Press. Surakarta. 2004.

Wignjosoebroto, Sritomo., 1995, Ergonomi, Studi Gerakan dan Waktu. Surabaya: PT Guna Widya. 